\title{
THE GRAMMAR OF DOMINATION AND THE SUBJECTION OF AGENCY: COLONIAL TEXTS AND MODES OF EVIDENCE1
}

\section{PREMESH LALU}

Grammar is politics by other means. ${ }^{2}$ We must delve into the archaeologies of the dead. ${ }^{3}$

\begin{abstract}
This article focuses on colonial accounts of the killing of the Xhosa chief, Hintsa, in 1835 at the hands of British forces along what came to be known as the Eastern Cape frontier. It explores the evidentiary procedures and protocols through which the event came to be narrated in colonial frames of intelligibility. In proposing a strategy for reading the colonial archive, the paper strategically interrupts the flow from an apartheid historiography to what is commonly referred to as "alternative history." The aim in effecting this interruption is to call attention to the enabling possibilities of critical history. This is achieved not by way of declaration but rather through a practice whereby the foundational category of evidence is problematized. The paper alludes to the limits of alternative history and its approaches to evidence on the one hand, and the conditions of complicity within which evidence is produced on the other. Whereas alternative history identifies its task as one of re-writing South African history, critical history, it is suggested, offers the opportunity to reconstitute the field of history by addressing the sites of its production and also its practices. In exploring the production of the colonial record on the killing of Hintsa, the paper seeks to complicate alternative history's slippage in and out of the evidentiary rules established by colonial domination even as it constitutes the category of evidence as an object for a politics of history of the present.
\end{abstract}

In alternative accounts of the South African past-alternative, that is, to the grids of colonial, liberal, and apartheid thought through which the past has been filtered-the particular story of the killing of Chief Hintsa in 1835 is frequently, and perhaps strategically, deferred to a third-person narrator or represented in the idiom of doubt. The habit seems to have been formed many years earlier in the literary and historical contributions of Samuel Mqhayi and S. M. Molema during the 1920s. Framed variously as a logical outcome of colonial advance, or in terms of the predictability of colonial violence

\footnotetext{
1 Qadri Ismail, Adam Sitze, Marissa Moorman, Gary Minkley, Leslie Witz, and Andrew Kincaid generously commented on an earlier draft. Thanks to the HSRC (South Africa) and the MacArthur Program (University of Minnesota) for financial support. The usual disclaimers apply. The article is part of a larger project that re-theorizes the historical event in colonial, nationalist, and historiographical accounts by reflecting on interventions made by Michael Taussig (on the frontier as a space of death) and the recent work of Pradeep Jeganathan, Qadri Ismail, John Mowitt, and Arjun Appadurai (on violence and disciplinarity). This article is an uncomfortably tentative gesture in the direction charted by these scholars. It is written for my colleagues in the History Department at UWC for their continued support.

2 Donna Haraway, Simians, Cyborgs, and Women: The Reinvention of Nature (New York, 1991), 3. 3 Mark Espin, "Beyond the Realm," unpublished poem, 1998.
} 
and the product of interpretation by those complicit in the act of murder, both writers preface their references to the event with a measure of doubt. Samuel Mqhayi, for example, in seeking desperately to narrate the story of the killing in terms other than those prescribed by a colonial archive, points out that while there is little doubt that Hintsa's body was mutilated and that his ear was cut off and sent to Grahamstown as a trophy, there is some doubt that his head was cut off. S. M. Molema in his The Bantu Past and Present, having identified Hintsa as the moving spirit behind the Sixth Xhosa War, repeats the sequence of events that have come to be associated with Hintsa's death: escape, pursuit by Smith, and shooting by Southey. Molema deflects all responsibility for the story by introducing the sequence of events with the phrase: "it is said." 4 The story of the death of a moving spirit is thereby entrusted to an anonymous third person, while the implicitly sarcastic gesture implied by such a deflection conveys a sense of narrative impasse.

That which colonial records described in terms of the treachery of the Xhosa was the sign of an incomprehensibility that would enable an alternative nationalist history of the event. The failure on the part of the colonial forces to anticipate Xhosa responses had far-reaching consequences for colonized subjects and the colonial expansionist project more generally. It also formed the basis on which colonial representations of the events leading up to the killing of chief Hintsa were built.

In more recent historiographical accounts of the colonization of the Xhosa, the story of the killing of Hintsa is told with extraordinary brevity and with references that lead us back to the colonial archive or through circuitous citations, to the palaces of power. Upholding a commitment to history from the perspective of the colonized, contemporary historians have sign-posted their invocation of colonial sources, alerting the reader to the dangers of an unfamiliar and a politically antagonistic descriptive vocabulary. Clifton Crais remarks, for example, that there "is no need to go into great detail recounting the war [in which Hintsa was killed]." It has been well described, he adds, particularly from the perspective of the colonists, by several authors. ${ }^{5}$ In proceeding, he stresses the emergence of conflict as a response to colonial expropriations of land and concludes with a summary of the event by suggesting that Hintsa attempted to negotiate with the colonial state and voluntarily entered the British camp in his territory. Made a prisoner, Crais adds, he attempted to escape, was hunted down, shot, and mutilated.

That which was said-in Molema's strategic phrasing-only manages a brief footnote in Jeff Peires's House ofPhalo with the rider that the entire court record that serves as historical evidence was extensively stage-managed by Smith and is of little relevance to the historian seeking to construct an alternative or truthful account of events. As in a recent textbook of the Southern African past by Neil Parsons, Peires manages only a few 
lines on the killing of Hintsa. ${ }^{6}$

In contrast to Crais, Parsons, and Peires, Timothy Stapleton, a historian of Xhosa experience and resistance to nineteenth-century conquest, offers a brief summary of the prehistory of the event-to borrow a phrase from Shahid Amin. In Stapleton's version D'Urban crossed the Kei River on 20 April 1835 and established a camp near the Wesleyan mission of Butterworth. Under the guise of punishing Hintsa for encouraging the Rharhabe attack on the colony, Stapleton claims that the governor declared war on the Gcaleka. After a campaign of terror in which kraals were burned and cattle seized, Hintsa and forty retainers, it is held, rode into D'Urban's camp to negotiate a settlement. The account then points out that they were subsequently disarmed and taken prisoner. Hintsa was instructed to surrender cattle and horses to the colonial forces and to accept responsibility for Rharhabe hostilities. In turn, says Stapleton, Hintsa sent a message to Maqoma describing his capture and warning the regent not to trust the Europeans. The conclusion of the story is that Hintsa was forced to accompany Smith's patrol on a mission to gather Gcaleka stock, and on 12 May was shot through the head by colonial soldiers, who proceeded to cut off the chief's ears. ${ }^{7}$

Narrative impasse stems from the manner in which the British cleared the scene of the crime, removed traces that may have enabled an alternative history, and left in its place only one story: their own. It seems ironic, though perfectly understandable, that alternative versions of the South African past should defer the narration of such a crucial event in history to the very perpetrators of murder. More importantly, the deferrals and doubts that frame an alternative history of the killing of Hintsa seem to suggest that colonial sources are useful in describing everything around the event but not the event itself. Phrased differently, why are colonial sources seen as reliable for accessing some aspects of Xhosa pasts but not others? How do historians discriminate between reliability and liability?

In the present article, I will explore the work that evidence performs (or does not perform) for alternative history of the event by unfolding the complex web of techniques and procedures through which it was produced within the logic of colonial domination. I am especially interested in how a primary discourse - understood in this instance as a field of intelligibility that is more or less the product of colonial rule-emerges as a primary source-understood as the raw material upon which the historian's practice rests. In other words, how is an institutionally bound discourse produced as an indispensable resource in the story of the killing of Hintsa? To pose the question along these lines is to ask that we attend to the very constitution of evidence. Evidence, whether in the form of the colonial archive or archive of opposition, does not necessarily provide a window to some prior reality nor should it only be evaluated in terms of the categories of "objectivity" and "bias." Rather, I suggest that by apprehending the procedures through which evidence is produced and the rules that inaugurate particular

6 Neil Parsons, A History of Southern Africa (London, 1982), 98-99; Jeffrey B. Peires, The House of Phalo: A History of the Xhosa People in the Days of Their Independence (Johannesburg, 1981), 112.

7 Timothy Stapleton, Maqoma: Xhosa Resistance to Colonial Advance (Johannesburg, 1994), 99. 
ways of knowing we may encounter an altogether different perspective on domination.

The article explores the modes of a colonial information economy, which rested on the tactics of intelligence and surveillance as it relates to the killing of Hintsa in 1835. My argument, briefly, is that the dismissal of colonial records as biased limits the possibilities of understanding the interior logic and effects of domination and unnecessarily suggests the possibility of an objective history of the event. Colonial domination could not have proceeded without the accommodation of the African in the narratives that it produced of the conquest of African societies, even when the narrative was explicitly premised on the will of the colonizer. The terms of that incorporation are crucial to an understanding of the pervasive logic of domination in the writing of history.

In some respects, the article is a tangential response to the question pertaining to the emergence of the colonial stereotype of "the African as enemy" posed by Martin Legassick in the closing moments of his erudite intervention on the frontier tradition in South African historiography. ${ }^{8}$ My response, however, is developed in a direction not provided for by Legassick's intervention. I do not wish to quarrel with his conclusions on the shift from master/servant to patron/client relations on the frontier, nor with the conception of the frontier as constituted by changing social relations. Mine is a modest appeal that asks us to pause on the question of the constitution of evidence and its consequences for narrating the killing of chief Hintsa along what came to be called the Eastern Cape frontier. The tactic may yield a story unimagined and unanticipated by the perpetrators of this cruel act of violence-a story in which we track the itinerary of the emergence of truth as "empirical" 9 and the social process of the subjection of agency. ${ }^{10}$

The question of agency as a sign of resistance that had preoccupied an earlier generation of social historians has been replaced in more recent historiographical interventions with a concept of agency as embedded in narrative possibility. Luise White, for example, affords us a view of written sources as a mode of narration that is constrained by oral narrative and "invaded" [her word] by orality. ${ }^{11}$

She insists on not treating oral and written sources as discrete narrative genres and thereby bypasses the objective/biased opposition that often structures history as a

\footnotetext{
8 Martin Legassick, "The Frontier Tradition in South African Historiography," in Economy and Society in Pre-Industrial South Africa, ed. Shula Marks and Anthony Atmore (London, 1980).

9 John and Jean Comaroff, Ethnography and the Historical Imagination (Boulder, 1992), 22. While the Comaroffs pursue this itinerary in terms of enchantment - a claim that recalls Adorno's "Dialectic of Enlightenment"-I wish to pursue the question in terms of the relationship of history to the empirical.

10 I am especially indebted to John Mowitt, Text: The Genealogy of an Antidisciplinary Object (Durham, N.C., 1992), which offers a provocative discussion in this direction. I would also like to acknowledge a debt to Spivak's discussion on metalepsis in Gayatri Chakravorty Spivak, The Post- colonial Critic: Interviews, Strategies, Dialogues, ed Sarah Harasym (New York, 1990), 122 and Judith Butler's discussion of speech and agency in her Excitable Speech: A Politics of the Performative (New York, 1997).

-+ Luise White, '"They Could Make Their Victims Dull': Genders and Genres, Fantasies and Cures in Colonial Southern Uganda," American Historical Review 100 (1995), 1381. For examples of attempts at problematizing oral histories see Isabel Hofmeyr, "Wailing for Purity: Oral Studies in Southern African Studies," African Studies 54, no. 2 (1995), 16-31; Carolyn Hamilton, Terrific Majesty (Cape Town, 1998); and Ciraj Rassool and Gary Minkley, "Orality, Memory and Social History in South Africa," in Negotiating the Past: The Making of Memory in South Africa, ed. Sarah Nuttall and Carli Coetzee (Cape Town, 1998), 89-99.
} 
discipline. ${ }^{12}$ The emphasis on genre, mediation, and narrative constraint relinquishes the burden of authenticity implicit in the promise of oral history. If, however, oral history was the means through which an obscured African agency was made visible, then how can we account for a concept of agency in what might amount to a "blurring of genres" of evidence ?13 $^{13}$

Without relinquishing White's innovative treatment of genre, the question of agency, it seems, may be posed in ways other than in terms of the autonomous subject or authorial subject. ${ }^{14}$ The emphasis on autonomous or authorial subjects readily lends itself to an identity politics and may be redeployed in ways that undermine the pursuit of an anti-apartheid history. If agency serves alternative history and identity politics, is it possible to recuperate a notion of agency without surrendering ground to a politics which establishes identity as an end game? To answer this question we may have to think of the ways in which agency is conditioned by the norms, practices, institutions, and discourses through which it is made available. In this sense the question of agency may also be posed in terms of the practices and procedures of evidence-making and the protocols of history-the social process, in other words, of the subjection of agency. To arrive at that possibility I wish to offer a brief reading of one example of the difficult relationship between genre and evidence in the South African context so as to pave the way for a consideration of colonial descriptions of the death of Hintsa.

II

Jeff Peires has pointed to a central problem of evidence and narration in an account of the 1856 Xhosa Cattle-Killing episode. The event-which incidentally has all the characteristics and problems that have come to be associated with the contemporary controversy surrounding the death of Hintsa-may be instructive in helping us to think about overcoming the narrative impasse that emerges in histories of acts of colonial

12 For an innovative use of this method see Hamilton, Terrific Majesty. The concept of mediation has been more thoroughly theorized by Raymond Williams, Keywords: A Vocabulary of Culture and Society (Oxford and New York, 1985) and Gayatri Spivak, "Can the Subaltern Speak?" in Marxism and the Interpretation of Culture, ed. Cary Nelson and Lawrence Grossberg (Urbana, 111., 1988). Spivak especially allows us to review what we take as the function of representation by invoking two terms from Marx, Darstellung and Vertretung. White's intervention points in this direction but is not theorized to the same extent. See also Spivak's more recent weaving together of "The Rani of Sirmur" and "Can the Subaltern Speak?" in Gayatri Spivak, A Critique of Postcolonial Reason: Toward a History of the Vanishing Present (Cambridge, Mass., 1999), 198-311, which revisits the question of the female informant in feminist historiography. This is not to deny the sophisticated historical critiques and critiques of history that address the objective/bias binarism. See, for example, Michel de Certeau, The Writing of Histoiy (New York, 1988); Paul Veyne, Did the Greeks Believe in Their Myths? transl. Paula Wissing (Chicago, 1988), 13 and 85; Dominick LaCapra, Rethinking Intellectual- History (Ithaca, 1983). Suffice it to say that outside of this critical tradition, the discipline of history retains its commitment to this facile and unproductive binarism.

13 The phrase belongs to Clifford Geertz. I acknowledge its reductionism in relation to White's specific intervention. Nevertheless, I am proposing a transactional reading in which the possibilities and promise of an overall intervention are temporarily suspended so as to contemplate the argument being pursued in a different direction. In this respect, I also stress that White's interventions extend beyond the limited reading suggested here. For an example where a reading of White in terms of Geertz fails dismally, -+ "The Traffic in Heads: Bodies, Borders and the Articulation of Regional Histories" Journal of Southern African Studies 23 (1997), 325-338. The focus on genre has gained widespread currency in recent African(ist) historiography. See for example Isabel Hofmeyr, We Spend Our Years as a Tale that is Told: Oral Historical Narrative in a South African Chiefdom (Johannesburg, 1994); Karin Barber, I Could Speak Until Tomorrow (Edinburgh, 1991) and Johannes Fabian and Tshibumba Matulu, Remembering the Present: Painting and Popular Histoiy in Zaire (Berkeley, 1996).

14 This is not to suggest that other formulations of the notion of agency (or oral narratives) should be jettisoned. The debate on gender and life strategies of women in African history has seen the concept of agency strategically mobilized to interrupt the modes of production narrative. See for exan 7+ Belinda Bozzoli, "Marxism, Feminism and Southern African Studies," Journal of Southern African Studies 9 (1983), 139-171; Susan Geiger, Tanu Women: Gender and Culture in the Making of Tanganyikan Nationalism (Dar es Salaam, 19 —* Heidi Gengenbach, "Truth-Telling and the Politics of Women's Life History in Africa," International Journal of African Historical Studies 27, 3 (1994), 619-627. 
violence and conquest more generally.

Peires's initial approach to colonial documents was one of suspicion and distrust. In The House of Phalo he argued vehemently against the use of colonial records, suggesting that they were filled with lies and innuendo. By the time Peires came to write his award-winning history of the Xhosa Cattle-Killing in 1989, he had substantially revised his position on the colonial archive and oral sources. In the preface to that book he argued that the primary sources which provide the evidence on which the historical account is based are riddled with lies, both "deliberate lies and self-delusions":

Most of the official documents, including almost all the printed official documents, are contaminated with references to the "Chiefs' Plot," the theory that the Cattle-Killing was a conspiracy by the Xhosa chiefs to bring about a war with the Cape Colony. If we leave the official documents to consult the archives which are stored in the memories of the old men of Xhosaland, we get the mirror image of the "Chiefs' Plot," namely "Grey's Plot," the theory that the root cause of the Cattle-Killing was a trick by Sir George Grey to deceive the Xhosa into destroying themselves. Today, there is hardly a Xhosa alive who does not believe that Sir George Grey was in some way responsible for Nongqawuse's prophecies. This made the writing of a history extremely difficult. ${ }^{15}$

After six years of examining "all the evidence on the Cattle-Killing," Peires argues that he is convinced that no plot existed on either side. He argued instead that the Cattle-Killing episode was a "logical and rational response, by a nation driven to desperation by pressures that people today can barely imagine."16 In 1990 Peires repeated his central argument in a special edition of the Radical History Review showcasing writing from South Africa. This time, however, he argued more forcefully that the claims made by Xhosa informants and elders were simply not true. Peires noted:

We have at our disposal in the Cape Archives a complete set of unofficial correspondence between Governor Grey and Colonel John Maclean, his chief subordinate in British Kaffraria. These letters, the equivalent of today's private telephone calls, are completely reliable and above suspicion. They prove beyond any reasonable doubt that far from masterminding the whole operation, Grey and Maclean spent most of their time trying to guess what was going on and what would happen next. Even if private letters did not exist, it is surely self-evident that no distant Victorian governor could ever have conceived so far-fetched a scheme, let alone blackened his face and hid in the reeds himself. But no matter how much contrary evidence is put before them, the Xhosa cling tenaciously to their belief that Grey was an initiator and originator of the whole calamity. ${ }^{15}$

In claiming the letters are more reliable than dispatches, an argument that is fleshed out in an earlier article in 1985 on Grey's manipulation of the evidence, ${ }^{16}$ Peires treats evidence as constituting a prior reality-prior, that is, to writing. Evidence, in this respect, is open to interpretation and to manipulation-that which is taken as the raw materials for the truth-claims of the discipline of history. The discrepancy that Peires detects between official dispatches and private correspondence need not, I wish to

15 Jeffrey Peires, "Suicide or Genocide? Xhosa Perceptions of the Nongqawuse Catastrophe," Radical History Review 46 (1990), 50.

$\longrightarrow$ Jeffrey Peires, "The Late Great Plot: The Official Delusion Concerning the Xhosa Cattle Killing, 1856-57" History in Africa 12 (1985), $253-279$.

https://repository.uwc.ac.za/ Pagel6 
suggest, be viewed in terms of the gradations of truth. Rather, we may think of evidence as produced under conditions of constraint. Evidence may then be thought of as an effect of a discourse. In other words, evidence is not necessarily a sign pointing to a prior reality but the very effect of power, in this case a colonizing project.

Peires's encounter with the written record, oral narratives, and truth is important for our purposes because it shows the foundational category of evidence upon which the discipline of history rests to be both contested and controversial. His project seeks to retrieve the very category of evidence to counter colonial and Xhosa explanations, and to suggest that the catastrophe may be understood in terms of a rational response to objective conditions. As a result he largely neglects the effects of evidence in relation to the emergence of subjectivity or as constitutive of the colonizing project.

The failure to grapple with the problem of evidence in ways that do not necessarily hinge on an objectivist concept of history was seized upon by Helen Bradford in an interrogation of the emergence of gendered subjectivity and the ways in which historiographical representations of the Cattle-Killing episode perpetuated rape myths and the marginalization of a subaltern woman called Nongqawuse. ${ }^{17}$ Bradford offers us a reading of the colonial record that suggests that Xhosa elders may have abused Nongqawuse-a possibility that has been altogether ignored by historians of the episode. The importance of Bradford's intervention does not only rest with the new causal explanation she offers, nor in her contribution to a more representative history that includes a subaltern woman in a story dominated by men as central actors. Equally important, in my view, is the question that Bradford asks about how and why the story of Nongqawuse came to be marginal and inconsequential in the first place. ${ }^{18}$ Although Bradford resolves that question by pointing to male bias in South African frontier historiography, I wish to argue that the question of marginality compels us to read evidence as structured by specific rules that both constrain agency and produce the subject as effect. ${ }^{19}$ It is the subaltern or subject effect alluded to-but unfortunately not developed-in Bradford's intervention that I wish to capture in the subsequent reading of colonial accounts of the killing of Hintsa.

III

\footnotetext{
-+ Helen Bradford, "Women, Gender and Colonialism: Rethinking the History of the British Cape Colony and its Frontier Zones, c. 1806-1870" Journal of African History 37 (1996), 351-370.

18 In this regard see also Patricia Hayes who has argued that "the empirical space — which is a symptom, not a disease-is there for a reason, a reason that needs to be theorized." See "The Famine of the Dams," in Namibia Under South African Rule: Mobility \& Containment, 1915-46, ed. Patricia Hayes, Jeremy Silvester, Marion Wallace, and Wolfram Hartmann (Athens, Ohio, 1998), 118.

19 There have been other instances where a potentially important critique of colonialism has been forfeited through a treatment of the colonial archive as biased. In his critique of Terence Ranger's study of the Shona-Ndebele uprising of 1896, Julian Cobbing contests Ranger's reading of the archive and his treatment of the Mwari and mhondoro cults as central to the rising. Cobbing draws on the charge of bias in seeking to refute the centrality of cults and emphasizing their conservatism. In this way the secrecy and uncertainty in colonial accounts are left completely unexplored in the interests of enabling a counter-narral -+ Julian Cobbing, "The Absent Priesthood: Another Look at the Rhodesian Risings of 1886-1887," Journal of African Histoiy 18 (1977), 61-87.
} 
In contrast to the brevity of contemporary historiographical accounts of the killing of Hintsa, the colonial record consists of more than 500 official documents of correspondence and reports on conditions in the Eastern Cape and 200 pages of military court records pertaining to the death of Hintsa. Countless adventure novels, diaries, memoirs, autobiographies, and travelogues must be added to this list. At first glance the size of the collection simply reaffirms our general sense of the bureaucratic apparatus upon which colonialism came to depend. A closer reading, however, suggests that the colonial archive is designed around several technologies of evidence-gathering and surveillance. It relies on strategies of cartography, autopsy, ${ }^{20}$ the building of alliances with the western Xhosa, missionaries' and traders' accounts, travelers' reports, and information gathered from a scattering of settlers on the frontier.

In these extensive-often arbitrary-networks of communication that came to be associated with colonial rule, the name of Hintsa is often mentioned alongside certain active verbs such as "contrive," "instigate," "plunder," and "invade" which emerge as stock phrases in dispatches from the Eastern Cape frontier to the administrative nerve centers of colonial rule in Grahamstown, Cape Town, and London. These grammatical orderings explain, to some extent, the subsequent manner in which Hintsa's death came to be described, understood, and judged in colonial circles. In the colonial context, these terms-which were reserved for the colonized-were neither unusual nor surprising. They suited and indeed qualified the object nouns of colonial rule-also known by the names "primitive," "uncivilized," "savage," and "Caffre." There was, however, a certain paradox in the configuration of the colonized as both capable of acts of intrigue and as objects of colonial rule. If the first of these conferred the possibility of agency on the Africans the second denied them any semblance of identity or agency of their own. Such a paradox militates, it seems, against the view of those who see in colonial texts a deliberate attempt to deny African subjects the capacity to act. ${ }^{21}$

It is striking that the deployment of these verbs and nouns, however, was neither random nor arbitrary. In fact, active verbs and object nouns were always organized and perhaps ordered within an accepted system of reportage common to colonial circuits of information and in relation to specific events-like the killing of Hintsa-which threatened the entire colonial psyche and its moralizing and civilizing claims.

Colonial officials did more than invent a vocabulary through which to describe the colonized as other. They also transformed themselves, in every manner of speaking, into victims of "savage" violence by surrendering their position as primary referent. Thus, Governor D'Urban wrote in one of his dispatches of missionary reports of the Xhosa in which the latter were represented as "wolves (which in truth they resemble very much) which, if they be caught young, may be brought to an appearance of tameness, but which invariably throw it off, and appear in all their native fierceness of the woods, as soon as

\footnotetext{
20 Francis Hartog's The Mirror of Herodotus (Berkeley, 1988) explores the relationship between observation and evidence at greater length. Autopsy is based on observational technologies but also privileges a form of evidence and proof.

21 Such paradoxes are by no means unique. Tejaswini Niranjana, Siting Translation: History, Poststructuralism and the Colonial Context (Berkeley, 1992), 3, argues that translation, paradoxically, also provides a place in "history" for the colonized.
} 
the temptation of blood and ravage, which never fail to elicit their natural ferocity, presents itself to their instinctive thirst for it."22 If such statements were clearly motivated by colonial racism, they may also be said to allude to the way in which colonialists presented themselves as victims rather than perpetrators-and this in spite of all their attempts at civilizing the Xhosa for what D'Urban thought to be "their own interests and gratification in the matter." 23

The reversal whereby colonial officials represented themselves as victims rather than perpetrators was achieved through two key mechanisms. First, by reversing the order of subject and object, the Xhosa (and Hintsa in particular) were guaranteed a certain agency. Hintsa after all could not be presented as a threat-as an instigator-if he had been rendered incapable of acting. Second, the need to confer upon the colonized subject an agency without denying the British the belief in their superiority or the very justification of colonial rule depended on a repressive tactic of colonial domination in which assumptions were transformed into facts: that tactic was given the sophisticated and surreptitious name of intelligence-gathering.

The collection of dispatches and reports that make up the bulk of the archive pertains to the communications between frontier and colonial headquarters in Grahamstown and Cape Town; between colony and metropole; and between traders, missionaries, colonial bureaucrats, and military officials situated in Xhosaland and along the frontier. Official reports generally relate to military strategy, the positioning of British troops, and the costs-both financial and in terms of the loss of troops-of the sixth frontier war. The letters of missionaries and traders based along the Kei River are mostly concerned with informing the colonial officials of the movements of the Xhosa along the frontier. Missionaries' and traders' reports were included as enclosures to support administrative reports and decisions, and were at times used to show that those settlers who lived among the Xhosa demanded more stringent measures than those undertaken by the military. In his report to colonial officials in Britain, Governor D'Urban cited the greater control demanded by the head of the Wesleyan mission in the Cape, W. J. Shrewsbury, who had "lived among the Xhosa and was therefore experienced in their character as in colonial frontier history." 24 Shrewsbury had written in January 1835 that "all Africans should be registered-every man wearing on his neck a thin plate of tin containing his name and the name of his chief-to identify offenders and enable the British government to know the number and strength of frontier tribes." 25 The claims of expertise and dominance were premised on a desire to know. The correspondence which forms such a core component of the colonial archive on the Eastern Cape, however, may also be read in

\footnotetext{
22 Cape of Good Hope: Caffre War and Death of Hintsa, Blue Book 279 of 1836 [Hereafter Cape of Good Hope], Dispatch from D'Urban to Earl of Aberdeen, 19 June 1835, 15.

"+ William Beinart has drawn attention to a similar tendency in his "Political and Collective Violence in Southern African Historiography" Journal of Southern African Studies 18 (1992), 455486. For Beinart "colonial or white settler thinking had an extraordinary capacity to invert causation for a whole range of social phenomenon [sic], including violence." The relationship of "thought," "capacity," "causation," and "social phenomenon" is, however, in need of further explanation. We may have to consider not only how thought performed such a mean feat but also which conditions enabled thought to perform this inversion. This may allow us to assess "thought's relationship to "violence" in slightly different terms. Thought and violence may be seen as mutually reinforcing operations rather than viewed within a logic of sequentiality.

24 Cape of Good Hope, D'Urban to Aberdeen, January 1835, 20.

25 Ibid., Shrewsbury to D'Urban, January $1835,41$.
} 
terms of an inability to penetrate the veils of secrecy that so confounded British forces in the period of the wars of conquest in the Cape. In a letter from the trader John Rowles on 17 December 1834, for example, we find suggestions of the limits of colonial knowledge. Rowles writes:

I can state, from my own knowledge, that Hintsa's chief councillors have been, for the last six months, - that is to say, from the period when Hintsa went to the upper country on the pretext of hunting-close communication with the frontier Caffers; - as soon as one of them returned, another was despatched and this intercourse was continued. Those councillors remained upward of a month before they returned to Hintsa. I never knew this kind of intercourse to subsist before between Hintsa and the Frontier Caffers. When I asked them what they had been doing among the Frontier Tribes, they made some trivial pretext, such as they went to get assegais, or some cattle or to pay a visit. ${ }^{26}$

Notwithstanding these limits, the colonial archive is organized around these fragmentary reports that came from informants located close to the centers of Xhosa political power and from an expansive administrative and military information economy. The traces of the diverse resources upon which colonial knowledge was based may be gleaned from a report from the governor, Sir Benjamin D'Urban, to the Secretary of State on conditions in the Districts of the Cape Colony on 19 March 1835. The report set out to identify the allies and enemies of the British among the Xhosa, a task that proved immensely important for British operations in the frontier zones. Toward the end of his report, he noted, with a hint of concern, that the strongest among the chiefs, Hintsa, seemed untrustworthy. In the report D'Urban noted:

Hintsa, the most powerful of them all (and whose territory extends from the mouth of the Kaie to its sources in the Stromberg Mountains, and between it, eastwards, and the Bashee) has been playing a double game. He has received the plundered cattle into his territory, some of his people have even undoubtedly joined the invaders, and his council (hemraaden) are decidedly hostile; but he himself professes not to be so, and so far as I can discover, in some communications which I have had with him during the last month, he is very desirous of holding off, to await the result of our first movements in advance, and then to act as may best suit his policy at the moment. In this, he may go farther than may be for his advantage; because, if he holds back from giving his essential assistance to the other tribes in the outset, he will weaken them, and when they are disposed of, will be left by himself to meet the ulterior proceedings upon our part, which, if we shall find it expedient to adopt them, I have little doubt we shall have discovered ample cause upon his, to justify our adoption. ${ }^{29}$

The report is a testament of the extent and importance of the colonial information economy. Judging from the regularity of such reports and the request for detail, the reports proved indispensable to supporters of colonial rule who had the opportunity to influence the colonial process at a distance. The suspicion of the double game, however, came largely from the reports produced by missionaries such as Shrewbury and traders such as John Rowles. To consider the implications of this uncertainty, let us look at a 
second report to the Secretary of State, dated 19 June 1835, to gauge the full consequences of the colonial information economy:

It may be in its proper place here to apprize your Lordship of my having, as early as the month of February, ascertained beyond all doubt that Hintsa (the chief of the country between the Kye and the Bashee) had been, if not the original contriver and instigator of the combination among the chiefs of the savage tribes in western Caffreland against the colony, very early referred to and consulted by them therein; that he afforded them his countenance and advice; received into his territory the plundered herds and effects sent thither from the colony; permitted (if not directed) many of his own tribe to join in the invasion; and that, consequently, the border tribes in all their measures relied on his support, and upon the ultimate refuge of his country in case of their failure. This certainty, afterwards still more amply confirmed, had rendered it obviously at once just and necessary that my operations should embrace the country of Hintsa as their concluding stage, and dictated the general outline of the plan of them which I gave confidentially to the chief of my staff for his information and guidance, and to which I had afterwards found it necessary to add the postscript in consequence of intelligence then received of a change in the movements of the border tribes. ${ }^{30}$

At first glance, there is very little discrepancy between the two reports. Both point to the threat posed by Hintsa and to the possibilities open to the British if these were to materialize. However, one small, though enormously consequential, exception for my argument emerges upon a closer reading. This relates to the certainty which frames the second report. If in the earlier report Hintsa's actions are presented in terms of possibilities, in the later report we learn that Hintsa had been guilty of conspiring with neighboring Xhosa against the British "beyond all reasonable doubt," and that there was a certainty that the events should end with the colonization of Hintsa's country. Between the doubt and the certainty, another event would guarantee the British the conclusion that they sought. That event was the killing of chief Hintsa on 12 May 1835.

Much of the literature dealing with the incident of Hintsa's death seems to suggest that it was the ability of the British to remain a step ahead of the chief that resulted in the colonization of the region of the Kei River. To achieve this, the British had to be fully aware and knowledgeable about what was occurring along the Cape frontier. However, it was not the certainties guaranteed by the information economy, but rather that which was beyond colonial horizons of comprehension-the movements, moods, and political alliances that were being forged outside the purview of the colonial state and its information-gathering apparatus - that prompted the British to colonize the land of the Gcaleka and to kill Hintsa.

The unknowable-or, more appropriately, the unverifiable-colonial imaginary was not only expressed in the period preceding the killing of Hintsa as demonstrated by the first report, or in racially charged claims that likened the Xhosa to "untamable wolves" ready to prey on colonial society as soon as the opportunity presented itself. If read extremely closely, the unknowable may be discerned from the very tone in which colonial officials such as D'Urban described the event in its aftermath as colonial officials set about to tell

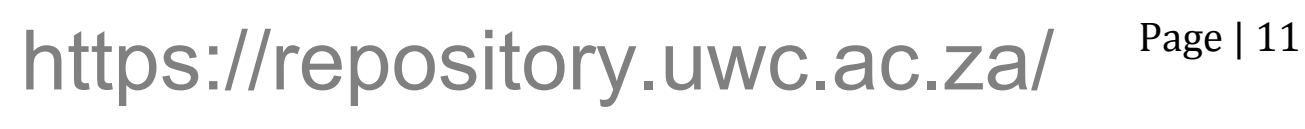


their story of a treacherous Hintsa who was responsible for his own downfall.

In D'Urban's report to Lord Aberdeen in June 1835, the governor set out to explain the circumstances surrounding Hintsa's death. Hintsa, in this version, entered the camp of D'Urban on 30 April 1835 to sign a peace treaty in which he agreed to a British demand for the "return" of 50,000 cattle and 1,000 horses in exchange for a cessation of hostilities. Upon signing the treaty, Hintsa apparently urged D'Urban to be allowed to remain at the camp with his son Crieli (Sarhili) instead of returning to his residence. Hintsa had offered himself as hostage to ensure that the British received the cattle and horses, which they demanded as part of the settlement. Initially this strange request was treated by D'Urban as a sign of goodwill but later, he claims, he came to see that the move was motivated by the fact that Hintsa feared being accused of selling out the Xhosa by forcing them to surrender the cattle and horses. By being a hostage at the camp, Hintsa could now claim to be a prisoner of the British forced to obey his captors' orders. But Hintsa, it was suspected, was conducting a war against the British and their allies (the Mfengu in particular) from within enemy lines. This was the double game alluded to in earlier reports. Hintsa, claimed the governor, was directing the attacks of chiefs residing in the Amatola mountains, and every message sent out in terms of the treaty was accompanied by another message-it was assumed-instructing a line of attack or a tactic to bewilder colonial forces as to the whereabouts of the stock they sought. The messages that were sent out to the Xhosa chiefs, Harry Smith would admit years later in his autobiography, were always secretive. ${ }^{27}$ After five days, Hintsa himself asked to be taken to his people accompanied by British troops so that he could attempt to convince them to surrender the remaining cattle. In this instance too Hintsa proved tentative in notifying the British where he was leading them. It was during this journey that Hintsa escaped and was subsequently shot in the head and killed while attempting to hide along the bank of the Nqabara River.

Two instances in the report are worth quoting, which may help to sustain the claim that an unverifiable colonial imaginary played a crucial role in the killing of Hintsa. The paragraph where the single reference to May 15 is made-three days after the shooting of Hintsa-states that the extension of the colonial border had become not merely expedient but absolutely and indispensably necessary and unavoidable. The statement reads as follows:

The only measure that could promise to repay the expenses of the war, which the colony had been most unwillingly compelled to wage pro aris etfocis, and place a defensible barrier between the heart of the colony and the savage tribes of Central Africa, provide security for the future, and a just indemnification for the past. ${ }^{28}$

This claim was not unusual. It bears all the characteristics of an expression of colonial arrogance that could claim victory in the face of such brutish acts against those it encountered as obstacles to its expansion. But it was really in the elaboration of that 
place between the heart of the colony and what is referred to as "Central Africa" that we encounter an anxiety produced by the unknown and the danger that was signaled by the failure to know. In the very next paragraph to the one just cited, D'Urban claimed:

A brief reference to the public correspondence of the Colonial Department with the successive governors of the colony for the years past, indeed ever since it has belonged to the British Crown (and its previous history, as a colony of Holland, is the same), will suffice to show that the main and insuperable impediment to its growing prosperity, and the source of its greatest misfortunes, have ever been the insecurity of its frontier, arising from the character of the country through which the advancing boundary line has been successfully traced; of this the two last extensions to the Fish River in 1812, and the Keishkamma and Chumie in 1819, are remarkable and incontrovertible instances. Both of these lines are involved in tangled jungles, impervious woody ravines, and in fact made by nature for the preparatory lurking place of the savage, before he springs upon his prey. ${ }^{29}$

Grappling with the insecurities of the frontier necessitated the successful tracing of the boundary line-that is a literal cartographic marking out of a territory that had been annexed. Cartographic claims, however, did not in and of themselves produce the desired securities. ${ }^{30}$ In February 1835, D'Urban informed the colonial secretary that even though the Keishkamma was mapped as belonging to Britain after the war of 1819, "Enno (sic), Bothman (possibly Bhotomane) and Dushanie's (sic)" people had concentrated forces in the strong and impervious country. ${ }^{31}$ D'Urban suspected that they had concealed themselves there awaiting the advance of British troops to trap the troops "for the purposes of further ravages." Each marking or tracing of annexed land by colonial officials, therefore, demanded further annexation and cautioned the supposed dangers left in its wake. The extension of the line to the Fish River, for example, also pointed to the Keishkamma and Chumie (or Tyhume). In 1835 it pointed toward the Kei River. Given that "all manner of danger lurked in those unknown spaces," the importance of plotting — of extending the traced line-was the only guarantee of security.

The unknowable, in the case of Hintsa, was not merely that which lay beyond the colonial gaze. Since Hintsa had located himself within the British camp after 30 April 1835 and directed affairs with Tyalie (Tyhali) and Maqoma from behind enemy lines, colonial officials increasingly doubted the reliability of their intelligence work. While they suspected that Hintsa was organizing an attack against the British, they were unable to decipher the messages-conveyed either in code or in secrecy according to D'Urban-that Hintsa had dispatched to the outer reaches of the frontier. Hintsa was capable of threatening the colonial project from both within and beyond colonial spheres

\footnotetext{
29 Ibid.

30 An earlier expedition by British forces against the Ngwane in 1828 led colonial forces across the Kei River to Mbolompo, south of the Mthatha River and the Mpondo chieftaincy. It did not lead to annexation of land but rather to the capture of labor. Those captured were taken to Fort Beaufort, according to Timothy Stapleton, and sold to white farmers. The capture resulted in the killing of $400 \mathrm{Ngwane}$ who had hidden in a nearby forest and to the capture of 100 women and children. Colonial officials claimed that the expedition was undertaken in the interests of saving the Ngwane from Hintsa and Vusani. Stapleton, however, suggests that it was an attempt to procure labor. Stapleton, Maqoma (Johannesburg, 1994), 56. See also Crais, Making of the Colonial Order, 98. Crais argues that the colonial state joined the Thembu, Mpondo, and Xhosa in the war against Ngwane and that many of the survivors were rendered destitute refugees or sources of servile labor.

31 Xhosa naming presented itself as a real difficulty for colonial officials. Reference to Dushanie in D'Urban's correspondence is often accompanied by the corrective "or T'Sambie."
} 
of control or surveillance. The sentiment of doubt expressed in the first report that D'Urban sent to the Colonial Secretary was therefore resolved through an act of violence in which those who threatened the extension of a line on a map and the securities that attended to that cartographic practice were killed and mutilated. Hintsa's death, in much the same way, was necessary for colonial expansionism.

If cartographic representations were produced in relation to what I have suggested were colonial insecurities and anxieties, how did these come to simultaneously produce a sense of security? To answer this question we may have to consider the way mapping worked and was organized in the Cape. According to J.S. Bergh and J.C. Visagie's cartographic guide of the Cape frontier zone, there were two maps that were central to the unfolding drama in the region. ${ }^{32}$ The first was drawn by surveyor-general C. C. Michell-listed in the Cape archive as map "Ml/2666 Military Sketch of the Route of the $1^{\text {st }}$ Division of the Army which invaded Caffreland in 1835 ...being sketched with accuracy by Chas. C. Michell, Surveyor General, Provl. A.Q.M., c. 1835." The second, a sketch map-"M 2/873 Eastern Province of the Cape of Good Hope and Kaffirland... with the movements [of troops] in March, April and May, 1835 in Kaffirland"- according to Bergh and Visagie was clearly carried and used by Governor D'Urban to record landmarks and place names as the invading force progressed. ${ }^{33}$

Maps, as Thongchai Winichakul reminds us, anticipate a spatial reality rather than serve as a scientific abstraction of reality. ${ }^{34}$ Anticipation, however, bears the signature of time so that maps preempt the configuration of an encountered space. ${ }^{35}$ Maps are therefore not merely representative but also preemptive. The work performed by the map is that of displacement and of negotiating the limits of the uncertain and the unknowable. Maps, we may argue, are constitutive of the will to power.

If D'Urban's map constitutes the conditions of the enhancement of power, then Michell's map-which bears the marks of the surveyors' skill-fixes the conditions of preservation. In D'Urban's map we have the replaying of the myth of the empty land. Xhosa polities are isolated and are represented through a singular symbolic inscription. No attempt is made to account for the expanse of Gcaleka, Ngqika, Gqunukhwebe, or Ndlambe settlements, nor are the interconnections reflected in any way. Instead we have a single symbol with the name Hintsa inscribed below. Whereas D'Urban's survey depicts the corresponding locations and movements of the first, second, third, and fourth divisions of colonial troops, Michell's map casts the territory as secure and is more detailed, representing the extent of the various chieftaincies and the areas of influence. If then D'Urban's map anticipated a reality-casting its gaze into a field of vision and opening it up so that from out of this possibilities may become apparent that will point

\footnotetext{
32 J. S. Bergh and J. C. Visagie, The Eastern Cape Frontier Zone 1660-1980: A Cartographical Guide for Historical Research (Durban, S.A. and London, 1985), 45-46.

33 Ibid. 46.

34 Thongchai Winichakul, Siam Mapped (Honolulu, 1994), 130

35 In this respect I have found the article by Phil Porter and Thomas Bassett on the elusive mountains of Kong very suggestive. Citing J. B. Harley, Porter and Barrett suggest that all maps state an argument about the world and they are propositional in nature. J -+ "From the Best Authorities: The Mountains of Kong in the Cartography of West Africa," Journal of African History 32 (1991), 367-413.
} 
the way to an enhancement of power ${ }^{36}$-Michell's appropriated the anticipated reality and re-presented it in terms of a scientific abstraction. Both power-enhancement and power-preservation belong to the will to knowledge.

Through cartographic practices, knowledge and colonial force coalesced to produce the securities for colonial officials and the possibilities for the actual annexation of land. Actual annexation laid to rest the insecurities that cartographic practices failed to produce. Cartography and colonization, it may be argued, were mutually reinforcing technologies of displacement, conquest, and murder.

Literature on colonial mapping underscores this argument. Simon Ryan asserts that in the Australian case, new inscriptions are first cartographical but also metaphorical of the transformation of the land by colonization-the cartographic inscriptions are not simply reflections of reality but organize and license the expropriation and exploitation of land. ${ }^{41}$ Similarly, Thongchai Winichakul's study of Siam and the mapping of the geo-body frames the relationship between cartography and conquest in terms that echo Ryan's central argument and that being developed in this paper:

Force defined the space. Mapping vindicated it. Without military force, mapping alone was inadequate to claim a legitimate space. But a map always substantiated the legitimation of the military presence. Mapping and military became a single set of mutually reinforcing technology to exercise power over space 42

An understanding of the effects of cartographic inscriptions is crucial to our understanding of the concept of the frontier in South Africa. The frontier was also a conceptual or imaginary formation premised on the rules of an information economy, cartography, colonial myth models, and colonial anxiety which had devastating political consequences for Xhosa polities. As in Ryan's argument, cartography in the Cape licensed colonization because it demarcated certainty and uncertainty, fear and security, the familiar and the unfamiliar. The colonial advance produced evidence inasmuch as it depended on evidence to affect its advance against Xhosa polities. The frontier, I wish to suggest, is not to be understood only as a place where social forces compete for claims to the land or authority. Rather it represented a conceptual limit, a mapped space, the formation of which had fundamental political and economic consequences for those caught in the way of its operation.

If, as John Comaroff has pointed out, there was a clash of three models of colonialism in the specific instance of the missionary imagination-a state model which emphasized trade and alliances with native chiefs, the settler colonialism of the Boers which converted independent chiefdoms into servile labor, and the civilizing colonialism of the missionaries-then perhaps it could be argued that these competing strands came together in the production of evidence that was so central to the annexation of land and so crucial to conceal that which was incomprehensible ${ }^{43}$ Insofar as each of these models contributed to knowledge of the Xhosa, and since they were each marked by discrepant 
interests, the evidence was always partial if not contingent.

The dominant concept of evidence that suggests itself in explaining the events leading up to the death of Hintsa is what we may call legitimation through knowing. Such knowing is premised on a wide-ranging set of techniques from intelligence-gathering to cartography to autopsy. Each of these technologies also proves inadequate in representing its object, which then establishes the limit to what is knowable. That which is unknowable must be confronted with an act of aggression. The unknowable always carries the potential of returning to haunt the securities established by neat lines on a map. Hintsa had shown how permeable those cartographic securities were, and in demonstrating the provisionality of colonial evidence he had to be destroyed. In ascribing motives for conquest, especially explanations derived from the suggestions of studies of the political economy of conquest, we would benefit from considering this overlap of evidence and colonization.

The description of the events leading up to the killing of Hintsa profoundly shaped and foretold the ways in which the actions of British soldiers were justified in colonial circles. Such justification proved important in providing both the moral high ground that colonialism claimed for itself and the basis for a response to accusations voiced by humanitarian groups in the colonies and the metropole. ${ }^{44}$ On 15 July 1836, less than one year after the killing of Hintsa, D'Urban instituted a military court of inquiry to investigate and report upon the circumstances immediately preceding and following the death of Hintsa, especially in light of the charge that he had been shot while begging for his life and the accusation that the dead chief's body had been mutilated after being shot. The military court established by colonial officials was a response to public debate that raged in the pages of the South African Commercial Advertiser and The Grahamstown Journal-and keenly followed by humanitarian campaigners in the metropole-on the question of the mutilation of Hintsa's body. The inquiry instituted by D'Urban differed from a regular criminal court since the former was solely aimed at verification or refutation of claims about mutilation and not at establishing guilt or innocence. 45

Verification and refutation, I wish to suggest, are forms of evidence that differ from earlier concepts of knowing. If knowing entails piecing together heterogeneous technologies through which information was filtered in partial ways, verification and refutation demand an exactitude in which the larger context is temporarily suspended. This difference is noticeable in both the kinds of questions that were posed by the commissioners and the immediacy with which they came to perceive the event. Thus, for example, the entire record is framed by questions such as: "What space and time elapsed between the shot that killed Hintsa and your meeting the Hottentots?"; "Was the time so short as to lead you to suppose that the Hottentots were present when the shot was fired that killed Hintsa?"; "Whom did you see on the spot when you came up

$$
\text { https://repository.uwc.ac.za/ Page|16 }
$$


to the body of Hintsa?"; "In what part of the body did he receive his mortal wound?"; "Did you think the brains you saw was the consequence of the gun-shot wound?"; and so forth.

In his study of the records of the military court of inquiry, Pretorious warns against too easy an acceptance of the explanation offered. According to Pretorious, it is unfortunately difficult to establish exactly what happened after Hintsa arrived in the British camp, because of the lack of disinterested evidence. Pretorious claims:

The official accounts - those of Harry Smith and D'Urban-were written only after the chief's death, and so were the accounts of other eyewitnesses. Not much importance should be attached to the depositions of chiefs and other persons collected by Smith after Glenelg had censured the D'Urban-Smith settlement. The whites among these persons, such as the Wesleyan missionaries, were all friends of D'Urban and Smith, while the Xhosa, such as Tyali and Maqoma, could have made their depositions under pressure or by means of the question-and-answer method, have been made to say whatever Smith wanted. All this evidence had the purpose of proving in retrospect certain things about Hintsa and must therefore be treated with utmost care..$^{37}$

There is good reason to acknowledge and to accept this caveat. The possibility of extensive British annexation that followed the death of Hintsa, or the strong chance that various testimonies were solicited under pressure, may have influenced claims made at the commission. Tyalie, one of Hintsa's closest allies, claimed that his people were never so happy since becoming British subjects and that Smith was their savior and "father."38 Such statements from a sworn enemy of the British must caution against too ready an acceptance of the testimony.

The recuperation of a story in which agentiary possibilities may be assigned to Hintsa is, however, constrained by the extensive way in which our encounter with the event is bound to confront colonial frames of intelligibility. These frames are significant in identifying the limits of a history that seeks to ascribe a place in the story for those formerly excluded or those who were victims of colonization. Pretorious, however, ignores the strategies through which these alternative possibilities are excluded. If evidence, as Arnold Davidson has suggested in reference to Carlo Ginzburg's interventions in this regard, is mediated by codes, then we need to "enter the codes of evidence" in order to gauge how they come to privilege certain claims against others. ${ }^{39}$ The point of "entering the codes of evidence" is not an attempt simply to detect interests and bias, but rather to explore the distribution of techniques that produce a facticity that is the foundation of evidence in service of a claim. At best, Pretorious offers us a first-order reading of the court record which situates the text within a larger cultural and political context, the extraneous conditions which have accompanied the text's

37 Jan Gabriel Pretorious, British Humanitarians (Pretoria, 1988), 179

38 Evidence by Tyalie, MF 1253, S A Library, Minutes of Proceedings of Court of Inquiry, 4 May 1836, 58.

39 Arnold Davidson, "Ginzburg and the Renewal of Historiography," in Questions of Evidence: Proof Practice and Persuasion across the Disciplines, ed. James Chandler et al (Chicago, 1994), 313 
production.

A second-order reading requires us to focus on the evidentiary strategies implicit in the text, which provide the basis for verification and refutation. In this respect, my suggestion is that we read the record in a way where the story of Hintsa produced by colonial officials is also necessarily a story that depends on the production of the subaltern as effect. In other words, the story of Hintsa can only be told by recourse to the marginalization of those actants who provided material for a different account of the killing of Hintsa. Here we must focus on the narrative distribution of Klaas (a member of the Corp Guides-a regiment composed of soldiers co-opted from local chiefdoms), the place of Hintsa, and those Xhosa along the banks of the Nqabara River who may have witnessed the killing of Hintsa and the subsequent mutilation of his body. ${ }^{40}$

Two charges emerged as central to the court record. The first claimed that Hintsa had been shot while asking to be taken prisoner, and the second that Hintsa had been mutilated after he had been shot. In his testimony to the commission of inquiry, Dr. Ambrose George Campbell claimed that the mutilation of Hintsa's body was proverbial and spoken generally in Grahamstown as a trophy of some consequence. ${ }^{41}$ There appeared upon the church-door, claimed Campbell, a number of lines of poetry, idolizing Southey (the soldier responsible for shooting Hintsa) as the savior of mankind; and part of Hintsa's body, whether his ears or his beard, was shown around Grahamstown as a mark of achievement.

Klaas, who was named by Campbell as one of his informants, proclaimed that he was close enough to the actual shooting to have heard the chief cry out "taru amapecati"-a cry for mercy-before a second and fatal shot was fired. Klaas also noted that Southey pursued Hintsa down the banks of the river and that he was accompanied by two members of the Cape Mounted Rifles called Windfogel Julie and Nicholaas Africa (identified in the records as Hottentots). After the shooting had taken place, Klaas (who is introduced as a Xhosa speaker) met Julie and Africa who inquired about the meaning of "taru"-a claim that confirmed that they had heard the chief's plea for mercy and that George Southey's failure to understand it proved fateful. Finally, Klaas pointed out that Hintsa's brain was exposed by the gunshot wound but that he could not tell for sure if the body had been mutilated-perhaps because he did not remain with the body for any significant length of time. Rather, the claim that Hintsa was mutilated emerged from the testimony of Julie and Africa-and later Dr. Laing of the $75^{\text {th }}$ Regiment-who had heard that Southey cut off the ear as trophy and as proof of having killed Hintsa.

A crucial mechanism used by the court of inquiry to vindicate the actions of Southey (and Colonel Smith under whose command the operation was carried out), and to discredit the testimony of Campbell, Klaas, Julie, and Africa, was to emphasize the importance of witnessing. Thus, in questioning Julie and Africa, proximity to the actual

40 I am currently exploring the ways in which Nomsa and Sarhili are invoked in the record as signs of intrigue.

41 Evidence by Campbell, MF 1253, SA Library, Minutes of Proceedings of Court of Inquiry, 29 August 1836, 1-2. 
shooting was emphasized over claims made on the basis of that which was heard. Witnessing-or autopsy-in this respect conveniently points to a more accepted and preferred form of evidence. Klaas's testimony was thus discredited because he was not a witness to the event:

COMMISSIONER: Did you know whether Hintsa had attempted to resist his pursuers in any manner?

KLAAS: He threw an assegai.

COMMISSIONER: When did he throw the assegai?

KLAAS: I only heard that he had thrown as assegai at Colonel Smith.

COMMISSIONER: Did you see Hintsa escape?

KLAAS: I was not near enough to see Hintsa running.

COMMISSIONER: If you were so far off as not to know who were pursuing him, how did you know that it was Mr. Southey who shot him? KLAAS: I did not see him, I only heard so. 42

Klaas's testimony, as it appears in the process of archival rearrangement, is important because it frames the rest of the questioning of the commissioners. It might be argued that while the outcome was not surprising, the method by which it was achieved is important, especially since it depended on the marginalization of testimony that may have been crucial to an alternative narrativization of the event. In this respect it was not coincidental that the testimony of Klaas is placed at the beginning of the record. The entire record hinged on discrediting claims based on what was heard and upon privileging that which was actually seen. ${ }^{43}$ Autopsy helped to refute what may have been heard and came to represent the only basis for verification. In this sense Klaas is rendered marginal to the unfolding commission of inquiry. However, all the commission's questions sought to prioritize that which was seen over that which was heard. In this respect Klaas's testimony-based as it was on what was heard-guided the questions of the commission as a whole.

Autopsy, in the end, proved insufficient to establish the colonial charge that Hintsa was responsible for his own death. First, the charge that Hintsa was involved in a conspiracy could not be proven through an autopsy. Second, the constant reference to the Xhosa who followed events from the opposite banks of the river may have produced an alternative version of the event that undermined colonial claims. Under these conditions it became necessary to prove that Hintsa was plotting against the British while claiming to be at their service.

Verification, it seems, could not do without justification. The threat that colonial officials speculated about in the period preceding Hintsa's killing emerged as an uncontested fact which was based on the testimony of chiefs (both Hintsa's allies and those co-opted by the British), missionaries, and traders. Following the testimonies of

\footnotetext{
42 Evidence by Klaas, MF 1253. SA Library, Minutes of Proceedings of Court of Inquiry, 29 August 1836, 3.

43 Hartog makes a similar claim in Mirror of Herodotus, 261. Citing Benveniste, Hartog claims that "if two men are in dispute [in litigation], one saying 'I saw for myself' and the other saying 'I heard for myself,' the one who says 'I saw for myself' is the one whom we must believe." That rule applies as much to other Indo-European languages as it does to Greek. The above is not always the case according to Benveniste who cites Latin as an aberration. Important for our purposes here is Hartog's claim that the juridical sense of history is premised on a definite connection between seeing and knowledge. This is similar to Hegel's sense of "original history" discussed in his philosophy of history.
} 
Campbell, Klaas, Julie, Africa, and Harry Smith (who provided the colonial justification for the killing of Hintsa), the court record re-introduces more than one hundred pages of letters from traders, missionaries, and military functionaries who had encountered the Xhosa east of the Kei River before the killing. The letter by Rowles that had suggested an inability to interpret the emergence of contact between the Xhosa on the frontier and Hintsa was now deployed as a justification for the shooting of Hintsa. Similarly, a letter dated 12 February 1835 from Captain A. B. Strong to Smith that raised concern over Hintsa's decision to move his people a short distance from the frontier was interpreted in 1836 as a plot aimed at threatening the security of British settlers. Finally, John Ayliff-a missionary based at Butterworth-who had earlier complained of Hintsa's secret intentions which were unsettling the missionary station, was read in the context of the court of inquiry as evidence of a conspiracy. To support the interpretation of this correspondence, the commission heard the testimony of Xhosa chiefs who-as Pretorious has suggested-were used to confirm Hintsa's guilt. Chief Eno (sic), a lesser chief in the Cape who had supported Hintsa's campaign against the British, stated that Hintsa, Tyalie, and Maqoma were in constant communication. ${ }^{44}$ This claim, which could have been read as an indicator of the permeability of colonial boundaries, now served the general case of the British who wished to establish the truth about a conspiracy.

The cumulative effect of these testimonies-especially that given by colonial sympathizers - was to shift responsibility unequivocally to Hintsa through the invocation of racist myth models frequently used to characterize colonized subjects. In the case of the chief's testimony, however, it is possible to discern amid the praises and gratitude for colonial rule the extent and limits of colonial intelligence-gathering and knowledge.

We have already noted that Hintsa's actions and behavior always bewildered colonial officials. No amount of translating of the movements of the Xhosa through reports and dispatches clarified the chief's position vis-a-vis the expectations of the British. Similarly, Hintsa's advice to Tyalie and Maqoma, informing them of the movements of the British-what might be called a counter-intelligence in the guise of surrender-hampered colonial attempts at retrieving cattle to finance the war. It was also a constant source of doubt about the dangers that lurked beyond the securities that colonial society had mapped out for itself. Most importantly, though, the best indicator of the limits of colonial knowledge was the inability to anticipate another story. In spite of all the collection of evidence- whether through heterogeneous techniques of information-gathering or through processes of verification and refutation-the fear that counter narratives could possibly emerge in the interstices of the uncertainty of colonial knowledge compelled the commission to summon Xhosa chiefs to declare their allegiance to the British and to implicate Hintsa in a conspiracy against those whom Tyalie called "British saviors." Outside of these institutional sanctions there were always other stories to be told. Those stories would, unfortunately, bear the traces of the massive colonial evidentiary base produced so as to defuse the tensions of empire. They were neither discrepant nor blurred; rather they were woven in a limitless but generically 
contradictory way so that the very concept of evidence was brought into question.

In 1996, Professor Shula Marks, the eminent social historian of South Africa, presented the Bindoff lecture at the University of London. The subject of the talk was the (re)writing of history in contemporary South Africa. Marks approached the topic by discussing the recent retrieval of a skull-allegedly that of Hintsa- by the healer-diviner, Nicholas Tilana Gcaleka. Gcaleka attributed his mission to a visitation by ancestors in a dream; he concluded that "South Africa would not experience peace until the head is returned. The rampant violence and corruption that plagues the new democratic South Africa is because the soul of Hintsa, shot dead and allegedly beheaded by the British in February 1835 at the end of the Sixth Frontier War 'is blowing all over the world with no place to settle."'45Having failed to prove the skull's authenticity by way of forensic testing and the archival record, Gcaleka had of course fallen victim to his own truth-game. He, after all, desired to be the agent seeking to fulfill the promise of his own dream- a case of the dream being conflated with the ego.

But all was not lost. In a bid to interpret the quest for the skull and in light of the failure to prove the skull's authenticity once discovered, Marks declared that Gcaleka was a man of his time. ${ }^{46}$ By this Marks meant that Gcaleka served as evidence of an identity that mediates the economic difficulties accompanying unfulfilled political promises in the post-apartheid period-the agent that mediates, and perhaps represents, a social reality. Now a double victim of his own truth-game, Gcaleka was to be mobilized against the

45 Shula Marks, "Rewriting South African History," Bindoff Lecture, University of London (June 1996), 6. See also Eddie Koch, "Mandela, the Chief and the King's Head," Weekly Mail and Guardian (February 16-22, 1996); Eddie Koch, "Chief's Head to be Put to the Test," Weekly Mail and Guardian (March 29-April 3, 1996).

46 The Makoni dignitaries, Philemon Zambe Makoni, F. C. Makoni, and J. C. Makoni, who went to Britain in 1987 to retrieve the head of Chief Chingaira Makoni, were also seen as men of their time. According to Terence Ranger they were possibly motivated by a succession dispute, by chiefly interests not wholly incongruent with those encountered in the tragicomedy of colonial administrators attempting to come to terms with "African tradition." Ranger claims that their quest—and its apparent congruence with colonial attempts to establish chiefly genealogies—vindicated his shift from nationalist history to a people's history; one culled from the rusty heads of poverty. In his recollection of the visit to Oxford by the Makoni representatives, Ranger points out that they had with them oral and other esoteric evidence and written sources-including his Revolt in Southern Rhodesia, 1896-7: A Study in African Resistance (London, 1979). Expressing polite astonishment at not being told the truth while in Makoni, Ranger was rebuked for pursuing the lives of peasants rather than those of the chiefs.

56. At this point in the text Ranger abruptly, and perhaps with a hint of irritation, ends the account of the meeting and hastily goes on to point out that these were the least likely men in Makoni to see the point of a people's history. For Ranger the meeting is illustrative of the preponderance of nationalist themes. In this respect the study of peasant consciousness that he had subsequently undertaken appeared premature as the mythic forms of cultural nationalism that gave Revolt in Southern Rhodesia its authority, persisted. The paradox is not merely thematic as Ranger has us believe. Equally crucial it seems is the implicit suggestion of the need to theorize the discrepancies that mark the times of history, discourse, and writing. In this way the declarative stance taken by Ranger could be substituted with an enabling critique. That such eminent scholars such as Ranger, Marks, and White have written about the controversies surrounding body parts and heads suggests that the matter cannot simply be treated as a site of nationalist mobilization. See Ranger, "Chingaira Makoni's Head: Myth, History, and Colonial Experience," Hans Wolff Memorial Lecture, African Studies Program, Indiana University, 29 March 1988. Here I must anticipate a critique similar to that made by Benita Parry of Gayatri Spivak, Abdul Jan-Mohammed, and Homi Bhabha, in which she claims that they are unable to listen to the voice of the native. Spivak responds as follows: "When Benita Parry takes us to task for not being able to listen to the natives, or to let the natives speak, she forgets that the three of us, postcolonials, are 'natives' too." See "Poststructuralism, Marginality" in Gayatri Chakravorty Spivak, Outside in the Teaching Machine (New York, 1993), 59-60. In her controversial essay, "Can the Subaltern Speak?" Spivak critiques Foucault and Deleuze for failing to advance a theory of interests. But rather than opting for recuperation, Spivak argues for developing work on the constitution of the Other as object and subject. Following Derrida, she argues that that project is also concerned with the constitution of Europe's ethnocentrism.

57. Although couched in different terms, I have found a recent article by B. Jewsiewicki and V. Y. Mudimbe rather reassuring in its call for pluralizing the research agenda of African history. See "+ "Africans' Memories and Contemporary History of Africa," History and Theory, Beiheft 32 (1993), 1-11 
postmodernists and post colonialists - themselves agents supposedly seeking to undermine the sacred domains of disciplinary history-as a sign of the legitimacy of what Marks calls materialist history.

Amid the clamor of Xhosa elites declaring Gcaleka a fraud and a charlatan (as Xolilizwe Sigcau had done) and the personal communications between Shula Marks and Jeff Peires (recall the authority conferred upon the personal communication in Peires's earlier reference), the possibility that Gcaleka's statement might be read as enabling or possibly critiqued in relation to the discourses, institutions, and practices that sanction truth-claims and which rendered Gcaleka a subject of his own truth-game, was completely overshadowed. Instead, the statement and also the man who had become a sign of the times were interpreted against the backdrop of-rather than against the grain of-the colonial archive and the expertise of the professional historian so as to illuminate prevailing socioeconomic conditions.

To critique Marks's interpretive reduction of the search for Hintsa's skull, we may ask how Nicholas Gcaleka became a sign of the times, and how the times came to be represented by Nicholas Gcaleka. ${ }^{56}$ For surely the question of materialism-the interpretive frame that Marks assigns to herself-begs a further question of materialization and the ways in which the latter is conditioned by specific rules and fields of intelligibility. This line of inquiry demands that we attend to the social process whereby agency is conflated with the agent-defined variously as object, subject, or mediator-by way of a study of the agency entailed in an activating dynamic-institutions, practices, fields of intelligibility, and discourses of intellectuals. The introduction of the activating dynamic into a study of history is an attempt at radicalizing the project of history so as to undercut the proliferation of essentialist identity politics that seeks to appropriate the work performed in terms of the recuperation of the marginal subject of history. In undercutting identity politics, the demand here is to intensify our efforts by producing more history-histories of concepts; critical histories of historical practices; histories that interrupt the discourse of capitalism and multiculturalism; histories of the formation of objects and subjects, systems of knowledge, and the elaboration of discourses. In this way the possibility arises of forcing identity politics - which relies so heavily on history for its legitimacy-into a space of self-referentiality where it must confront its limits and interests as it struggles strategically but in a scrupulously visible way. In the wake of the ascendancy of identity politics, one task might be to consider what possibilities-ethical and political-lie in the alternative and potentially enabling practice of history as criticism.

\section{CONCLUSION}

The challenge to historians reading the colonial archive, it seems to me, is to point out the inconsistencies (where it stutters in its articulation, as Guha so eloquently puts it) in the story of colonialism and to mark these as the sites where other stories may have 
taken place. To claim that subaltern consciousness, voice, or agency can be retrieved through colonial texts is to ignore the organization and representation of colonized subjects as a subordinate proposition within primary discourses. While colonial discourses are premised on a subordinate will- Foucault would say that silence and marginality are constitutive of a discourse - that will is neither representative of a subaltern collective consciousness nor independent of the determinations of a colonial will. We might then seek to retain a sense of the colonized as an unfathomable point of irreconcilability-what Spivak calls misfits of the text-in dominant frames of intelligibility. To claim that colonial texts unwittingly permit a recuperation of the subaltern is to declare a premature victory. It is to surrender the consciousness or will of subaltern subjects to the workings of colonial domination.

We need to approach that which is often mistakenly perceived of as subaltern consciousness in colonial records as an effect of domination rather than as representative of the consciousness of the underclasses. What we are treated to in colonial texts is not the presence of the subaltern but the mechanics of Europe producing itself as sovereign subject through its Other. One cannot hope to retrieve a silence(d) subject (as has been suggested in some recent historiography) by way of the colonial archive. Reading against the grain, to use Pam Scully's naming of a tactic whereby the colonial archive is mined for subaltern agency, ${ }^{47}$ is perhaps more usefully deployed as a practice of criticism rather than as an attempt to represent. As I suggest in this article, agency has already been organized in relation to a condition of domination. We may then read the colonial archive in terms of a practice of criticism which, according to Ranajit Guha, starts with examining the components of a discourse, the vehicle of all ideology, for the manner in which these might have described any particular figure of speech. ${ }^{48}$

\section{University of the Western Cape Bellville, South Africa}

\footnotetext{
47 Pamela Scully, Liberating the Family? Gender and British Slave Emancipation in the Rural Western Cape, South Africa, $1823-1853$ (Cape Town, 1998). In the work of Terry Eagleton and Gayatri Spivak the idea of reading against the grain assumes a different tactical implication. Spivak suggests that a reading against the grain is enabled by moments of transgression in the text. But transgression is not seen in terms of an invasion- $a$ la White. Rather it is intrinsic to the very operation of the Law. Transgression may interrupt or bring a discourse to crisis, but it can never reveal a transcendental subject. Gayatri Spivak, A Critique of Postcolonial Reason: Toward a History of the Vanishing Present (Cambridge, Mass., 1999).

Pamela Scully, Liberating the Family? Gender and British Slave Emancipation in the Rural Western Cape, South Africa, $1823-1853$ (Cape Town, 1998). In the work of Terry Eagleton and Gayatri Spivak the idea of reading against the grain assumes a different tactical implication. Spivak suggests that a reading against the grain is enabled by moments of transgression in the text. But transgression is not seen in terms of an invasion- $a$ la White. Rather it is intrinsic to the very operation of the Law. Transgression may interrupt or bring a discourse to crisis, but it can never reveal a transcendental subject. Gayatri Spivak, A Critique of Postcolonial Reason: Toward a History of the Vanishing Present (Cambridge, Mass., 1999).
}

48 Ranajit Guha, "The Prose of Counter-Insurgency," in Subaltern Studies II (Delhi, 1983), 9. 